\title{
PENERAPAN VISUALISASI TENTANG VAKSIN COVID 19 MENGGUNAKAN PENDEKATAN BAHASA DAERAH MANGGARAI SEBAGAI UPAYA MENINGKATKAN KESIAPAN MASYARAKAT MENERIMA VAKSIN
}

\author{
Lidwina Dewiyanti Wea ${ }^{1 *}$, Egidius Mera ${ }^{2}$, Maria Ivany Suryati ${ }^{3}$, Dorotea \\ Nasvia ${ }^{4}$ \\ Email Korespondensi : lidwinawea88@gmail.com \\ ${ }^{1-4}$ Universitas Katolik Indonesia Santu Paulus \\ Disubmit: 14 Juli 2021 \\ Diterima: 23 Juli 2022 \\ DOI: https://doi.org/10.33024/jkpm.v5i2.4675
}

\begin{abstract}
ABSTRAK
Pandemi covid 19 telah membawa banyak perubahan dalam tatanan kehidupan masyarakat. Pandemi juga menimbulkan keresahan akibat banyaknya masyarakat yang harus di rawat di pusat-pusat kesehatan bahkan angka pasien yang meninggal semakin meningkat dari ke hari. Hal ini membuat konsentrasi dunia tertuju pada bagaimana cara untuk bisa memutus mata rantai penyakit ini. Telah banyak upaya yang dilakukan mulai dari pembatasan aktivitas masyarakat, penerapan regulasi penanganan, aturan menggunakan masker, mencuci tangan dan menjaga jarak dan yang terbaru adalah dihasilkannya vaksin sebagai upaya pencegahan penyakit ini. Ditemukannya vaksin tidak serta merta membuat masyarakat merasa lega namun banyak juga masyarakat takut menerima vaksin akibat kurangnya mendapat informasi. Dengan adanya pandemi yang tidak memungkinkan penyampaian informasi dilakukan secara langsung maka metode sosialisasi menggunakan visualisasi dirasa lebih tepat untuk diterapkan. Visualisasi merupakan cara menyampaikan informasi menggunakan gambar secara daring. Tujuan dari kegiatan ini adalah memberikan pemahaman kepada masyarakat umum terkait vaksin covid 19 dengan menggunakan pendekatan Bahasa Daerah agar lebih mudah di pahami. Hasil kegiatan ini meningkatkan pengetahuan tentang vaksin dan vaksinasi covid 19 serta tingkat kecemasan menjadi berkurang, dimana $85 \%$ peserta mengatakan puas dengan informasi yang disampaikan dan mereka menjadi lebih mengerti serta kecemasan mereka menjadi berkurang. Pemberian vaksin covid 19 di lakukan secara bertahap dan membutuhkan waktu yang lama untuk dapat menjangkau seluruh masyarakat, karena itu sosialisasi masih terus perlu dilakukan dan menjadi program edukasi wajib di berbagai tempat dan media.
\end{abstract}

Kata Kunci: Covid 19, Vaksin, Visualisasi

\section{ABSTRACT}

Covid-19 pandemic brought enormous change in the society. Pandemic also creates anxiety due to the increasing number of infected people treated in health care facilities and increasing number of the disease mortality rate. Thus, it is undeniably a worldwide concern to stop the disease transmission. Plenty of efforts have been carried out namely activity restrictions, disease control and management, mask use guidelines, hand washing and social distancing, and the 
more recent is vaccination in order to stop this disease transmission. The vaccine discovery does not instantly creates relieve amongst the society, moreover, the vaccine hesistancy is occured due to the lack of information. Pandemic creates social distancing made the direct information delivery is difficult to be done, thus, the online visual socialization is deemed more suitable. The aim of this activity is to provide understanding to the general public on covid-19 vaccination using local language to make it easier to perceived. The result of this activity is the increasing knowledge on Covid-19 vaccine and vaccination, and reducing the anxiety level among the participants. $85 \%$ of participants said that their knowledge increases and their anxiety. Covid-19 vaccination will be conducted gradually and take a long time to access all of the population, thus a continuous socialization is a vital education program in every place and media.

Keywords: Covid 19, Vaccine, Visualization

\section{PENDAHULUAN}

Pada awal tahun 2020, dunia dikejutkan dengan adanya pandemi covid 19. Penyakit ini di sebabkan oleh virus SARS-Cov-2 yang menyerang system kekebalan tubuh. Virus ini diketahui pertama kali muncul di Wuhan, Cina dan sejak kemunculannya telah banyak memakan korban jiwa (Fadini, G.P, Morieri, M.L, et al, 2020). Data yang dilansir pada worldmeters.info menyebutkan jumlah kasus korona di dunia per 18 Februari 2021 mencapai 110.540.408 kasus, meninggal 2.443.160 dan jumlah kasus sembuh mencapai 85.428.741 orang. Di Indonesia dilansir dari sumber yang sama menyebutkan data total kasus adalah 1.252 .685 , kasus baru +9.039 kasus, total jumlah kematian 33.969, kasus baru kematian +181 , total kasus sembuh adalah 1.058.222.

Fokus dunia terarah pada upaya pengendalian serta pencegahan penyakit. Banyak upaya yang telah dilakukan mulai dari mewajibkan penggunaan masker, mencuci tangan dengan sabun, aturan untuk menjaga jarak, membatasi aktivitas sosial, perkantoran, sekolah, pasar, dan lainlain. Berbagai upaya yang telah dilakukan tersebut tidak cukup membuat dunia keluar dari pandemi ini. Dalam upaya mengatasi pandemi ini, banyak negara telah menghasilkan vaksin yang digunakan untuk negara itu sendiri dan juga di ekspor ke negara lain. Sejumlah perusahaan seperti Pfizer, Moderna, Oxford-AstraZeneca, hingga Sinovac berlomba-lomba mengembangkan vaksin covid-19 (Medcom.id, 2021).

Vaksinasi secara massal diakui sebagai langkah mengakhiri pandemi ini (Pearl, R., 2020). Dengan ditemukan dan disediakannya vaksin, ditemukan juga berbagai kendala seperti masalah distribusi, biaya dan juga terkait ketidaksiapan dan ketidakmauan dari masyarakat untuk menerima vaksin akibat kurangnya informasi. Pengetahuan tentang covid-19 sangat penting (Sari \& Atiqoh, 2020). Dalam masa pandemi ini, penyampaian informasi secara langsung tidak dapat dilakukan secara maksimal dan tidak bisa menjangkau banyak orang mungkin di sebabkan karena kurangnya akses terhadap informasi yang dberikan melalui media cetak dan media elektronik. Hasil penelitian Sabarudin, dkk., 2020 menggunakan media video dan leaflet mendapatkan hasil bahwa ada perbedaan sebelum dan setelah edukasi secara online dengan $p$-value 0.001 . Komunikasi melalui media massa seperti media sosial merupakan hal mendasar dari berbagai 
media promosi yang dirancang untuk mengubah perilaku yang beresiko terhadap kesehatan (Alber et al.,2016).

\section{MASALAH}

Kabupaten Manggarai sebagai salah satu kabupaten di Propinsi NTT yang memiliki banyak kecamatan dan desa-desa. Untuk mengakses informasi, masih banyak penduduk yang mengalami kesulitan terutama untuk wilayah yang jauh dari perkotaan. Kondisi ini menyebabkan masyarakat terlambat menerima informasi dari pihak - pihak yang berkaitan dengan vaksin seperti perawat dan bidan malah masyarakat lebih cepat menerima informasi yang disebarkan dari mulut ke mulut yang kebenarannya pun tidak dapat dipertanggungjawabkan. Sebagai contoh, masyarakat takut menerima vaksin karena mendengar informasi ada efek samping yang membahayakan, akan muncul demam, tidak enak badan, dan sebagainya. Jika tidak dijelaskan dengan baik efek samping tersebut maka masyarakat tidak akan mau di vaksin.

Sosialisasi dan edukasi yang terus menerus dilakukan adalah bentuk upaya memberikan pemahaman kepada masyarakat, dan bentuk sosialisasi dapat berupa penyuluhan untuk memberikan informasi mengenai pencegahan dan penanganan covid 19 (Anggunan, dkk.,2021). Metode penyampaian informasi dapat di berikan dengan berbagai cara, salah satu metode yang efektif saat masa pandemi adalah dengan metode visualisasi. Metode visualisasi merupakan cara yang digunakan untuk menyampaikan sesuatu informasi melalui gambar bergerak yang di sebarkan secara daring. Metode visualisasi dapat disimpan dalam media seperti MP4, dan disebarkan via Whatsapp Grup, Facebook, instragram sehingga masyarakat dapat mengaksesnya dengan mudah dan berulang-ulang.

\section{METODE}

Kegiatan sosialisasi ini dilakukan dengan cara menyebarkan video sosialisasi secara daring melalui media online (Facebook dan Whatsapp). Shalahudin (2021) dalam Hervina, dkk (2021) menyatakan bahwa proses pemberian materi pembelajaran pada masa pandemic covid-19 dapat dilakukan melalui media Whatsapp yang menunjukkan hasil positif dimana terjadi peningkatan pengetahuan masyarakat.

Kepada puskesmas - puskesmas dan puskesmas - puskesmas pembantu diberikan file video yang disimpan dalam flash disk. Tujuannya jika diperlukan dapat diputar pada layar LCD saat program penyuluhan rutin di puskesmas dan puskesmas pembantu.

\section{HASIL DAN PEMBAHASAN}

Dalam kegiatan ini ada beberapa tahap yang dilalui yakni:

1. Kajian Materi

Tahap ini merupakan tahap awal yang bertujuan mencari sumbersumber pustaka yang relevan sebagai bahan dalam materi visualisasi. Setelah materi disusun menggunakan Bahasa Indonesia kemudian diterjemahkan ke dalam Bahasa Daerah Manggarai 
2. Desain Video Visualisasi

Materi yang telah di terjemahkan ke dalam Bahasa Daerah Manggarai kemudian di tulis dalam bentuk naskah yang dapat digunakan dalam tahap record audio. Tim juga membuat visualisasi dalam bentuk gambar agar lebih mudah dipahami dan menarik untuk di simak

3. Penyempurnaan dan Finalisasi Desain

Materi visualisasi harus memenuhi beberapa unsur terkait diantaranya, definisi covid 19, penyebab covid 19, tanda dan gejala, waktu pemberian vaksin, mekanisme kerja vaksin covid 19, efek yang ditimbulkan pasca vaksin, dan berbagai hal lain yang terkait disesuaikan dengan maksud pada gambar apakah sudah sesuai gambar dengan isi materi dan tujuan yang akan disampaikan.

4. Sosialisasi

Setelah tahap finalisasi, tahap selanjutnya adalah tahap sosialisasi tentang materi visualisasi agar bisa diketahui oleh banyak orang. Pada tahap sosialisasi dilakukan secara daring (online) melalui media Facebook dan WhatsApp menggunakan video visualisasi dengan durasi \pm 2.5 menit. Hal-hal yang dipaparkan dalam video adalah pengertian vaksin dan vaksinasi, tujuan, syarat penerima vaksin dan yang tidak bisa menerima vaksin, efek pasca vaksin, dan informasi pendukung lainnya. Semua isi materi menggunakan Bahasa Daerah Manggarai. Peserta dan masyarakat yang telah melihat dan mendengar video sosialisasi kemudian diambil beberapa sampel untuk ikut dalam pengisian form evaluasi untuk mengetahui respon masyarakat terkait materi dan model sosialisasi visual ini. Evaluasi dilakukan dengan menggunakan google form dan pertanyaan yang diberikan berupa pertanyaan kualitatif.

Berikut beberapa hasil evaluasi :

\begin{tabular}{l}
\hline $\begin{array}{l}\text { Materi sosialisasi sangat menarik dan mudah dimengerti karena } \\
\text { menggunakan Bahasa Manggarai }\end{array}$ \\
\hline Karena sinyal terputus, kami susah untuk mengunduh materi \\
\hline Kami baru mengerti setelah mendengar sosialisasi ini \\
\hline Memang lebih bagus kalau pakai Bahasa daerah, lebih paham \\
\hline Materi sosialisasi ini membuat kami tidak bingung lagi tentang vaksin \\
\hline Bagus pakai Bahasa daerah, tidak banyak istilah medis yang kami tidak tahu \\
\hline Sebaiknya sosialisasi ini juga dimasukkan ke radio supaya lebih banyak \\
masyarakat yang tau
\end{tabular}

Masa pandemi menyebabkan aktivitas sosial dibatasi, termasuk kegiatan penyuluhan - penyuluhan di tempat pelayanan kesehatan seperti puskesmas dan puskesmas pembantu tidak dapat dilakukan secara langsung, namun demikian penyampaian informasi harus terus dilakukan. Salah satu cara adalah dengan pendekatan visualisasi. Pendekatan menggunakan visualisasi sebenarnay telah banyak dilakukan, bahkan menggunakan teknologi-teknologi yang lebih bagus dan menarik, namun hal tersebut tidak dapat menjangkau kalangan menengah kebawah yang secara tingkat pendidikan tidak dapat memahami isi materi yang disampaikan. Setyawan (2011) menyebutkan penggunaan bahasa dari segi sosiolinguistik lebih menitikberatkan pada bagaimana fungsi bahasa daerah sebagai salah satu pilihan bahasa yang digunakan secara tepat sesuai dengan kondisi dan situasi yang sedang terjadi. Untuk itulah kegiatan ini dibuat dengan membuat materi visualisasi ini ke dalam 
Bahasa Daerah Manggarai. Bahasa daerah sebagai Bahasa Ibu dirasa cukup efektif dalam mempengaruhi masyarakat dan membuat masyarakat lebih mudah untuk memahami apa yang disampaikan. Trudgil (1974) dalam Setyawan (2011) menyebutkan bahasa memiliki fungsi sebagai sarana membangun hubungan sosial dan sarana efektif dalam memberi informasi terhadap lawan bicara. Materi dan cara sosialisasi menggunakan pendekatan visualisasi ini memungkinkan percepatan penyampaian informasi kepada seluruh masyarakat sehingga kapanpun vaksin diberikan masyarakat dapat lebih siap. Hasil penelitian Wiliyanarti, dkk Tahun 2021 terkait efek penggunaan video sebagai media pembelajaran dan edukasi pada siswa sekolah dasar membuktikan bahwa terjadi peningkatan pengetahuan siswa tentang penerapan protokol kesehatan.

Berikut ini adalah gambar beberapa potongan-potongan video visualisasi:

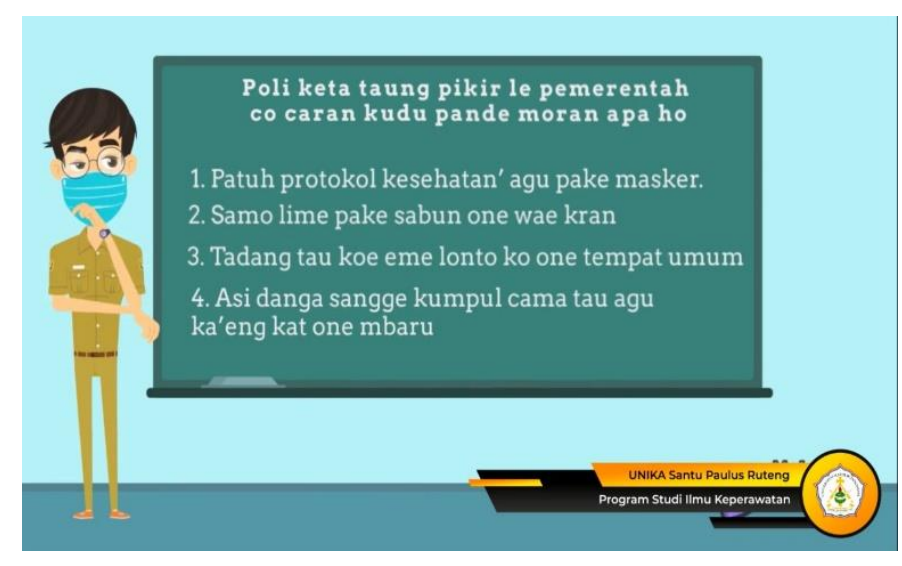

Gambar 1. ini menerangkan bahwa pemerintah telah berpikir cara-cara mengendalikan dan mengurangi dampak penyebaran virus covid-19

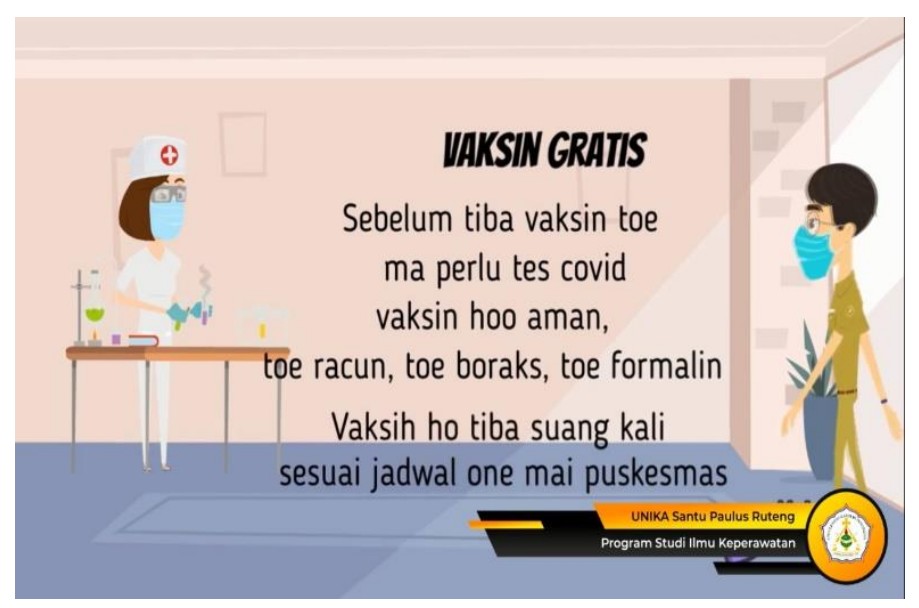

Gambar 2. ini menerangkan bahwa vaksin yang digunakan ini aman, vaksin bukan racun, bukan boraks, tidak mengandung formalin. Vaksin diberikan sebanyak $2 x$ sesuai jadwal pemberian dari Puskesmas setempat 


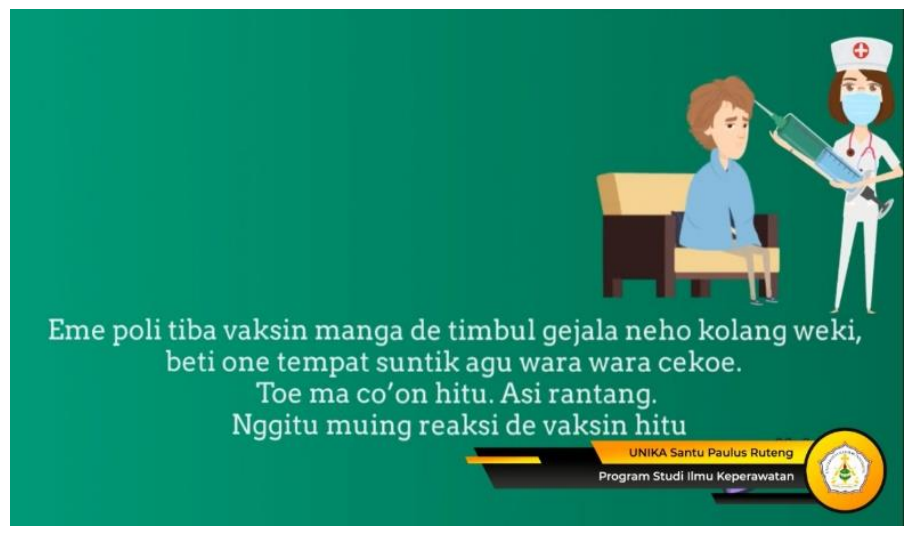

Gambar 3. ini menerangkan bahwa setelah di vaksin akan timbul beberapa gejala wajar seperti demam dan sakit disekitar area suntikan, namun tidak berbahaya

\section{KESIMPULAN}

Dapat disimpulkan bahwa pemberian edukasi dapat meningkatkan pengetahuan masyarakat. Sosialisasi menggunakan pendekatan visualisasi yang disebarkan melalui media online dapat bermanfaat terutama dalam percepatan penyampaian informasi kepada masyarakat. Dan pendekatan Bahasa Daerah merupakan cara yang digunakan untuk membuat masyarakat lebih mudah untuk memahami maksud dari materi yang disampaikan. Metode ini dapat digunakan oleh para tenaga kesehatan baik di perkotaan maupun pedesaan sehingga tidak membutuhkan waktu yang lama untuk dapat memberikan sosialisasi kepada masyarakat mengingat apabila dilakukan secara langsung membutuhkan waktu, tenaga dan biaya yang cukup banyak. Ditambah medan perjalanan di wilayah - wilayah tertentu yang susah dijangkau. Karena kegiatan vaksin dengan sasaran masyarakat umum masih membutuhkan waktu yang lama, maka kegiatan sosialisasi masih harus terus dijalankan.

\section{DAFTAR PUSTAKA}

Alber, J.M., Paige, S., Stellefson, M., \& Bernhardt, J.M. (2016). Social media selfefficacy of health education specialist: training and organizational development implications. Health Promotion Practice, 17 (6), 915-921. Doi: https://doi.org/10.1177/1524839916652389

Anggunan, Maki, M.A.H.A., Jhonet, A., Hasbie, N.F., Silvia, E., Wulandari, M. (2021). Penyuluhan Tentang Penanganan dan Pencegahan Covid-19. Jurnal Kreativitas Pengabdian Kepada Masyarakat (PKM), 4(2), 263-267.

Worldmeters info. (2021). https: //www.worldometers.info/coronavirus/ . diakses pada 23 Maret 2021.

Medcom.id, 2021. "Ini beda tiga jenis vaksin covid-19 berdasarkan bahan dasar". Jakarta: Medcom.id. Diakses pada 23 Maret 2021.

Fadini, G.P., Morieri, M.L., Loangato, E., Avogaro, A. (2020). Prevalence and impact of diabetes mellitus among people infected with SARS-CoV-2. Journal Endocrinological Investigatio. 43(6): 867-869. Doi: https://doi.org/10.1007/s40618-020-01236-2 
Hervina., Nasutianto, H., Astuti, N.K.A (2021). Konsultasi dan Edukasi Masalah Kesehatan Gigi dan Mulut serta Protokol Kesehatan selama Masa Pandemi Covid-19 secara Online melalui Teledentistry. Jurnal Kreativitas Pengabdian Kepada Masyarakat (PKM). 4(2): 299-306.

Pearl, R. (2020). The Queen's Gambit and Covid-19: Why It's All about the End Game Now. Diakses melalui : https://www.forbes.com/ sites/robertpearl/2020/12/07/the-queens-gambit-and-covid-19-its-allabout-the-end-game-now/?sh=1cc0447d3f8a pada 23 Juli 2021.

Sabarudin, Mahmudah, R., Ruslin., Aba, L., Nggawu, L.O., dkk. (2020). Efektivitas Pemberian Edukasi secara Online melalui Media Video dan Leaflet terhadap Tingkat Pengetahuan Pencegahan Covid-19 di Kota Baubau. Jurnal Farmasi Galenika. 6(2): 309-318. Doi: https: / / doi.org/10.22487/j24428744.2020.v6.i2.15253

Sari, D.P., Atiqoh, N.S. (2020). Hubungan Antara Pengetahuan Masyarakat dengan Penggunaan Masker sebagai Upaya Pencegahan Penyakit Covid-19 di Ngronggah. Jurnal IImiah Rekam Medis dan Informatika Kesehatan. 10(1), 52-55. Doi: https://doi.org/10.47701/infokes.v10i1.850

Setyawan, Aan. (2011). Bahasa Daerah dalam Perspektif Kebudayaan dan Sosiolinguistik: Peran dan Pengaruhnya dalam Pergeseran dan Pemertahanan Bahasa. International Seminar "Language Maintenance and Shift" https://core.ac.uk/download/pdf/11735959.pdf diakses pada 23 Juni 2021 